\title{
UNIVERSITYOF
}

FORWARD

THINKING

WESTMINSTER用

WestminsterResearch

http://www.westminster.ac.uk/westminsterresearch

The role of spirituality in business education

Illes, K. and Zsolnai, L.

This is an author's accepted manuscript of an article published in Society and Business Review, Vol. 10 Issue: 1, pp.67-75.

The final definitive version is available online at:

https://dx.doi.org/10.1108/SBR-07-2014-0034

The WestminsterResearch online digital archive at the University of Westminster aims to make the research output of the University available to a wider audience. Copyright and Moral Rights remain with the authors and/or copyright owners.

Whilst further distribution of specific materials from within this archive is forbidden, you may freely distribute the URL of WestminsterResearch: ((http://westminsterresearch.wmin.ac.uk/)).

In case of abuse or copyright appearing without permission e-mail repository@westminster.ac.uk 


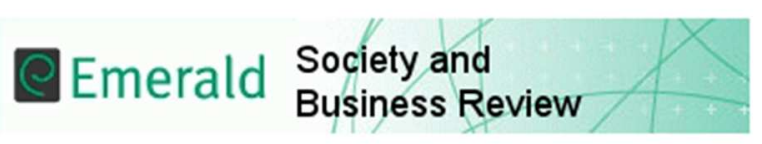

The Role of Spirituality in Business Education

\begin{tabular}{|r|l|}
\hline Journal: & Society and Business Review \\
\hline Manuscript ID: & SBR-07-2014-0034 \\
\hline Manuscript Type: & Original Article \\
\hline Keywords: & Management Development, Social responsibility, Business \\
\hline \multicolumn{2}{|c}{} \\
\hline
\end{tabular}

SCHOLARONE $^{\text {m }}$

Manuscripts 


\section{The Role of Spirituality in Business Education}

Purpose: The paper argues that there is a strong imbalance in business education between providing abstract, rational concepts and opportunities for personal growth. Introducing spirituality in business education seems to be desirable if we want to prepare students for the complexities and challenges of the workplace today.

Design/methodology/approach: The paper gives an example of how techniques from voice and drama therapy can be used for enabling students to look beyond the rational and the material.

Findings: By engaging with their 'true self' students may discover dormant qualities in themselves and start to find their purpose, meaning, and spirituality.

Originality/value: The paper shows that by introducing some new approaches in business education we can provide opportunities for students to connect their rational thoughts with conscience and the 'true self'. When students make an integrated use of our mental, emotional and spiritual resources they are better equipped to make complex decisions and behave ethically in the workplace and in their personal lives. 


\section{Business Profession in Crisis}

Irresponsible and insensitive behavior of business leaders worldwide suggests that business is an under-professionalized occupation today. Rakesh Khurana, Nitin Nohria and Daniel Penrice of Harvard Business School argue that if management was a licensed profession on a par with law or medicine, there might be fewer opportunities for corporate bad guys. (Khurana, Nohria \& Penrice 2005)

Sociologists studying the professions have employed a range of criteria for determining what makes an occupation a mature profession. Four criteria are important to set forth the essence of the "bona fide" professions like law and medicine. Criteria for calling an occupation a "bona fide" profession are as follows:

(i) common body of knowledge resting on a well-developed, widely accepted theoretical base;

(ii) system for certifying that individuals possess such knowledge before being licensed or otherwise allowed to practice;

(iii) commitment to use specialized knowledge for the public good, and a renunciation of the goal of profit maximization, in return for professional autonomy and monopoly power;

(iv) code of ethics, with provisions for monitoring individual compliance with the code and a system of sanctions for enforcing it. (Zsolnai, Junghagen \& Tencati 2012)

In comparing business management with the more traditional professions of law and medicine along these criteria is wanting. This shortcoming has a direct bearing on society's ability to demand and obtain responsible conduct from executives, as well as on management's ability to maintain the public trust required for the optimal functioning of our economic institutions. (Khurana, Nohria \& Penrice 2005: 1)

We can agree with Joel M. Podolny, former dean of Yale School of Management, who emphasis that occupations are defined as professions to the degree to which they serve society. And unless management lives up to that service standard, it frankly calls into question what business schools are actually doing (Podolny and Khurana 2007, p. 9).

\section{Problems with Business Education}


The criticism offered by prominent business scholars and practitioners shows that something is deeply problematic in business education today.

In his famous paper "Bad Management Theories Are Destroying Good Management Practices", the late London Business School professor Sumantra Ghoshal points out that by propagating ideologically-inspired amoral theories, business schools have actively freed their students from any sense of moral responsibility (Ghoshal 2005: 76).

Ian I. Mitroff of University of Southern California in Los Angeles, claims that business school faculties are at best guilty of having provided an environment where corporate misbehavior could take roots and flourish. At worst they are guilty of being active accomplices and co-conspirators in criminal behavior (Mitroff 2004).

According to Mitroff the problem is that business schools have promulgated

(i) a mean-spirited and distorted view of human nature (by assuming that humans are completely and entirely ruthless, motivated solely by greed, and purely opportunistic);

(ii) a narrow, outdated, and repudiated notion of ethics (materialistic egoism);

(iii) a narrow and highly limited definition of the role of management (management is about making money and can be captured solely in economic terms);

(iv) an overly reified conception of the sub-disciplines of management (a fragmented and separated division of interrelated issues);

(v) a sense of learned helplessness and hopelessness among business professionals regarding control of their lives (maintaining an attitude that they have no power to change the system in which they find themselves). (Mitroff 2004)

Eleanor O'Higgins of the University College Dublin and Yvon Pesqueux from CNAM Paris believe that management education as presented in the medium of business schools has acted as a cheerleader for the management models and practices. This is manifested and reinforced by (i) the managerialist perspective; (ii) deference to powerful stakeholders, especially companies/prospective employers of students, and students themselves as 'consumers'; (iii) simplistic tools and formulas to train students; (iv) academic tenure and promotion systems; and (v) the extremes of popularist science and pedantic science (O'Higgins and Pesqueux, 2008). 
Paul Shrivastava of the John Molson School of Business, Concordia University in Montreal, warns that the Occupy Wall Street movement questions core principles that govern modern corporations - principles ostensibly taught by today's business schools. He argues that at present, most business schools teach corporate leaders the art of making money and fail to examine fair corporate governance. There is not a surprise that corporate managers, educated without adopting an ethical viewpoint, do not have the framework to address the moral outrage over the societal and environmental impacts of big business that led to the burgeoning criticism of Occupy Wall Street and other counter-movements (Shrivastava 2011).

\section{Educating the Whole Person}

Mintzberg (2004) criticied the business curricula (especially MBA programs) arguing that people who take these courses will only be equipped with scientific tools for analysis and decision making. Consequently they will be without the art and craft of leadership and can cause more harm than good in high level corporate positions.

The rhetoric is changing in business education but that does not necessarily mean the change of the dominating mind-set and behavior. Business education has yet to embrace the responsibility of preparing students for life by giving them opportunities for self-discovery, and for development of personal mastery and integrity.

Business education in its current form provides plenty of opportunities for the acquisition of rational knowledge. There is no shortage of support for those who buy into the ideology that promotes financial success as a measurement of value. Character formation, the development of virtues seems to fall outside the remits of business education (Walls, Platts, and Illes 2007). It can be argued that character is formed in the family and throughout primary and secondary education and in education for the profession only specific scientific and technical knowledge should be transmitted. But ethics and value-commitment are fundamental part of any mature profession and hence professional education has to deal with this problem.

Many authors have called for a fundamental reform of business education. Some have argued that our traditional educational approaches are deeply rooted in a mechanistic view of management and leadership evoking the illusion of predictability and control (Berends and Glunk 2006), whereas daily experience in the workplace shows that events are not necessarily pre- 
dictable or controllable. Even the deployment of increasingly sophisticated information and decision support systems cannot take away the need for human judgment. Business practice shows that success in managerial and leadership roles depends to a great extent on the level of maturity, growth, self-awareness and personal mastery (Covey 1992; Platts 2003).

Developing one's character and morality requires willingness and courage to embark on an individual journey of self-discovery. It cannot be pre-determined and prescribed by neatly boxed learning objectives. It is a personal quest that is easier to follow when one sees that others around him or her are also focusing on their own challenges. The Greek word 'scholé' means free space. Originally a school was a retreat where people could reflect together with others on how the world weaves into a whole, what they and others ought to do, and how the good life can be defined, attained and lived. School is a place where people are relieved of the task of making a living, taking care of others, or serving specific interests. Schooling is making use of this free space to inquire into ideas that guide humans' doings and to explore the meaning of concepts and ideas that inform their activities. It is a joint effort, because one' ideas and ideals need to be 'honed' by those of others. In the progression of such an inquiry a team is forged in which participants can develop their personal view of excellence in action. And this in turn opens the way towards a vision shared by all. (Kessels, et.al. 2004)

Schools in their original sense have played an important role in the formation of character and morality over the centuries. It would be timely to re-introduce the concept of 'free space' of inquire in business education and encourage students to formulate their own ideas through dialogue and personal reflection before they set their foot on the corporate ladder (Illes 2004).

Copenhagen Business School professor Peter Pruzan argues: "What is clearly needed is a change in the mind-set, values and principles of our leaders, as well as of those who finance our enterprises, and of those who teach and mentor our future leaders. At the very minimum, what is needed is an expansion of the concept of 'success' so that it transcends the prevailing myopic focus on short-term financial gains.” (Pruzan and Pruzan 2007: 6)

Encouraging students to formulate their own definitions of success is one of the first basic steps that business school professors could do. Allowing time and creating opportunities to 
explore questions about meaning and the idea of a 'good life' can give students a chance to formulate their own ideas about life in line with their conscience.

When we continuously "educate and obey our conscience" (Covey quoted in Pruzan and Pruzan 2007: 53) we develop our character and act according to spiritual principles even if we decide not to label them in that way. "Spiritual-based leaders respect others and are guided by the fundamental ethic: service to others comes before serving oneself. From an existential perspective, the raison d'être of organizations is to serve human needs. Really, there is no other reason for their existence. Individuals and organizations grow when they give themselves to others. Relationships improve when there is a focus on serving the other, be it at the level of the individual, the family, the organization, the community, the society or all of humanity". (Pruzan and Pruzan 2007: 52)

Hungarian poet Sandor Weöres explains perhaps even more clearly what it means to fulfill one's human nature and morality: "Virtue is all that is equal to the eternal measure and lifts you towards wholeness; sin is all that opposes the eternal measure and distances you from wholeness. One who has reached wholeness becomes one with the eternal measure and has no virtue or sin any more. He or she becomes similar to the fire. The light is not the virtue of the fire but it is its nature. Similarly one who has achieved wholeness has the eternal measure not as a virtue but as part of his or her nature. In wholeness there is no good and bad, no merit and mistake, no reward and punishment." (Weöres 2000, III: 28 translated by the authors).

By including philosophy, ethics, and wisdom traditions into the curriculum of business education and allowing time and free space for honest dialogue on them professor can enable students to make the shift from competition to collaboration, from knowledge hoarding to knowledge sharing, from exploiting private opportunities to contributing to the overall wellbeing of society.

\section{“Discover Your Leading Qualities" Workshops}

There is a disconnect between learning about leadership and improving one's leadership qualities. The authors believe that everybody has the potential to lead and the ability to follow. When we are connected with our purpose we tap into an energy that fuels our desire to grow and we develop all skills and competencies we need to fulfill our purpose. 
It is through the embodiment of 'true self' that leaders and followers are perceived authentic (Ladkin and Taylor 2010). Connecting to the 'true self' is not primarily an intellectual process and through the somatic sense of self one can experience a felt sense that confirms his or her level of authenticity. By the techniques used in voice and drama therapy one can understand and experience the connection between the physical, emotional and spiritual aspects of his or her self. This felt sense enables the person to release his or her trapped energies and discover new qualities within.

Between 2009 and 2011 one of the authors (Katalin Illes), working with a voice and drama therapist, offered 10 stand alone workshops of approximately 2 hours duration to students of all faculties at a large UK university. The workshops and the research were funded by the University's Arts Council. The events were advertised by emails and flyers across the two campuses of the university. To attend an extra curriculum workshop required a certain level of curiosity, searching and readiness from the students. Participants came from arts, languages, and science, nursing, education and business backgrounds. They represented a variety of nationalities and were between the age of 21 and 45. There were between 10-15 participants in each workshop. At the end of the event participants were asked both for verbal and a brief written feedback.

The purpose of this research was to explore if it was possible to trigger the desire for selfdiscovery in university students by introducing them to techniques used in voice training, mindfulness and drama therapy. We intended to help participants to understand and experience the connection between the internal and external world and notice the interconnected nature of the physical, emotional and intellectual aspects of themselves. We offered an opportunity for self-discovery in a journey from the rational towards the spiritual through experiencing the felt sense. The workshops were set up as action research and the researcher used self and participant observation, reflection and participant feedback to record the experiences and the outcomes.

During the sessions techniques of vocal exercises, role plays, improvisation, creative writing and personal reflection were used. By creating a safe and trusting environment we enabled individuals to develop a connection between their abstract, intellectual views on leadership 
and their personal, bodily embedded experiences of leading and following. Participants had opportunities to take on both leading and supporting roles during the workshops.

The "Discover your Leading Qualities" workshop was inspired by Stanislavski's work. Stanislavski (1948) believed that an actor must work all his life, cultivate his mind, train his talent systematically and develop his character. Stanislavski's requirements can only be fulfilled by those who are passionate and fully committed to their chosen profession. The word actor in the quote can be substituted by any other profession and the statement will still hold true.

The voice (similar to movement in Tai Chi or yoga) is a bridge between the inner and the outer worlds. If the voice is free it can reflect the inner world with great accuracy (Houseman, 2002). The body and the voice are expressions of the self, showing our ease or lack of ease with ourselves and the world. They cannot be bullied into shape so getting to know the body and the voice and fulfilling their potentials requires patience and commitment and need to be an integral part of one's journey of development.

The safe, trusting and light hearted atmosphere of the workshops enabled individuals to establish a connection between their abstract, intellectual views on leadership and their personal, bodily embedded experiences of leading and following. By changing the question from "What is leadership?" to "What are my leading qualities that I can use to serve with passion?" leadership became a personal experience and developing one's talent a personal responsibility.

The facilitators experienced a real life leadership challenge because they never knew who would turn up for the workshops. They could not be sure about the number of participants or their interests and background. It meant that we (the facilitators) depended a great deal on our own authenticity and intuition. We created a safe space to experiment, improvise and articulate previously unexplored dreams, ideas and feeling about one's leading qualities and future ambitions. This in the moment, spontaneous creative process energized participants and held the group together as an authentic community on a shared journey.

Each workshop was different both in content and in interaction. In order to succeed the facilitators had to have a high level of intuition, improvisation, courage and trust in each other and the process. The methods we used in the various workshops included rational thinking, work- 
ing with the five senses, reflective and meditative exercises. Participants came with a level of curiosity and uncertainty and by the end of the workshops there was a sense of co-creation. We all worked at individual and group levels and by the time we closed the sessions there was a noticeable bond among the participants.

All workshops were well received and students left the room feeling energized and ready to take new steps on the journey of self-discovery. We received appreciative comments and thanks after the events and the voluntary written feedbacks also confirmed that the free space and the guidance towards the inner self were valuable and necessary triggers for participants. The workshops indicated that by discovering our own leading qualities we open up the possibility for establishing a closer, more interconnected relationship between our external and internal journeys and are also starting to develop our authentic self. When we are working with the qualities that reflect who we really are we come fully alive and are ready to help to create a culture of sharing and collaboration around us.

Participants in the workshops were 'seekers'. They were ready to give up some free time in search to experience something different to standard academic interaction. After the initial "I don't know what to expect" hesitation participants responded very well to the unusual offerings of the sessions.

Below is a selection of comments from the written feedback the workshop organizers received.

\section{What were your expectations from the workshop?}

Came with an open mind; a lecture on leadership; presentation; listening for 3 hours and not doing anything

What did you like in the workshop?

Creativity, interaction; by breaking the barrier we were all together; singing, playing; nothing it was not for me, sorry

\section{Have you discovered anything new about yourself?}

I can speak in public! My future depends on me; not to limit myself; I like to perform; I need to change my outlook on life

\section{What else would you like to experience in such a workshop?}

More singing; more opportunities to talk in public; work on body language; not sure; some more presentation skills

\section{Would you recommend this workshop to a friend?}

More than 90 per cent of participants said 'yes' to this question 


\title{
Would you like to hear about future workshops? \\ More than 90 per cent of participants said 'yes' to this question
}

\begin{abstract}
After the workshops further emails were received from some participants asking about techniques of personal discovery and development, meditation and reflection. These students were keen to take on further extra curriculum activities to continue their self-discovery. The workshops indicated that by discovering our own leading qualities we open up the possibility for establishing a closer, more conscious and interconnected relationship with others when leading or following.
\end{abstract}

The debriefing sessions and the participants' written feedbacks show that students who attended the workshops wanted to focus more on developing their leading qualities while studying at university.

The ten workshops were also valuable for the facilitators. It made them realize that further efforts are needed to transform their interaction with their students creating more opportunities for personal discovery, reflection and deep experiences. They realized that by focusing on the original meaning of education professors can help to bring out the hidden qualities and potentials in students and prepare them more fully for the complexities and challenges of personal and professional life.

\section{Conclusion}

Business education has a growing responsibility to provide students not only with up-to-date expert knowledge but also with learning opportunities for developing responsibility for their true self, for fellow human beings and for the environment. Business schools should educate not only the brain of their students but also their heart.

Self-discovery and spending time getting to know their 'true self' is a crucial part of the development of future business professionals. By directing students towards their inner selves professors can enable them to expand their consciousness and to see their lives as part of the universal human experience. 
Creating learning opportunities where students can move from the tangible and rational things towards the intangible and spiritual experiences is an important challenge for business educators. If professors want to lead their students not only in subject-specific technical matters but also in personal development they need to be able to connect rationality and spirituality in their classrooms. (Bouckaert and Zsolnai (eds) 2012) Talking about spirituality might be intellectually stimulating but it is not enough. Professors teach primarily not by what they say but by how they live and behave.

\section{References}

Berends, P. and Glunk, U. (2006), "Personal mastery in management education: The case of a personal development trajectory in graduate education" Paper presented at the 13th EDINEB Conference, Lisbon.

Bouckaert, L. and Zsolnai, L. (eds) (2012), The Palgrave Handbook of Spirituality and Business. Palgrave, London.

Covey, S. R. (1992), The Seven Habits of Highly Effective People. London: Simon \& Schuster

Ghoshal, S. (2005), "Bad management theories are destroying good management practices", Academy of Management Learning \& Education, Vol. 4, No. 1, pp. 75-91.

Illes, K. (2004), “Missing components of management education" Paper presented at the $2^{\text {nd }}$ International Philosophy of Management Conference, Oxford.

Kessels, J., Boers, E. and Mostert, P. (2004), Free Space and Room to Reflect: Philosophy in Organisations, Amsterdam: Boom

Khurana, S., Nohria, N. \& Penrice, D. (2005), “Is business management a profession?”, Harvard Business School Working Knowledge, February 21. 
Ladkin, D. and Taylor, S.S. (2010), "Enacting the 'true self': Towards a theory of embodied authentic leadership" The Leadership Quarterly 21: 64-74

Mintzberg, H. (1994), Managers Not MBAs. San Francisco: Berrett Koehler

Mitroff, I. (2004), “An Open Letter to the Deans and the Faculties of American Business Schools, University of Southern California, manuscript.

O’Higgins, E. and Pesqueux, Y. (2008), "Management education - A path to business integrity?", in L. Zsolnai et al (Eds.): Ethical Prospects: Economy, Society and Environment, Springer, Dordrecht, the Netherlands, pp. 41-62.

Houseman, B. (2002) Finding your Voice. London: Nick Hern Books.

Platts, J. (2003), Meaningful Manufacturing. York: William Sessions Limited

Podolny, J.M. and Khurana, R. 2007 “Can we make management a profession?”, $Q 1$ - A Publication of Yale School of Management, Spring, pp. 9-26.

Pruzan, P. \& Pruzan, M. K. 2007 Leading with Wisdom: Spiritual-based Leadership in Business. Greenleaf Publishing, Sheffield.

Shrivastava, P. (2011), “Occupy Wall Street: A wake-up call for business schools", La Presse, October, 29, 2011, Montreal, Quebec (in French).

Stanislavski, C. (1948) The Actor Prepares, Routledge

Wall, S., Platts, J. and Illes, K. (2007), "Choices and responsibilities: A human centric approach to university-industry knowledge transfer" British Academy of Management Conference, Warwick.

Weöres, S. (2000), A teljesség felé (Towards Wholeness). Budapest: Tericum.

Zsolnai, L., Junghagen, S. and Tencati, A. 2012: "Redefining the Roles and Duties of Management" Journal of Global Responsibility 2012 vol.3, no. 1, pp. 121-133. 